\title{
Implementation of Reproductive Health Gymnastics Against Female Adolescents Hemoglobin Level
}

\author{
Sarah Fitria ${ }^{l, *}, R r$. Sri Endang Pujiastuti ${ }^{2}$, and Donny K. Mulyantoro ${ }^{3}$ \\ ${ }^{1}$ Midwifery Department, Master of Applied Health, Poltekkes Kemenkes Semarang - Indonesia \\ ${ }^{2}$ Nursing Lecturer, Postgraduate Program, Poltekkes Kemenkes Semarang - Indonesia \\ ${ }^{3}$ Health Research and Development Center, Magelang - Indonesia
}

\begin{abstract}
Anemia in female adolescent has a risk to women's health, both short and long term which will disrupt the life cycle of women. Reproductive health exercises adopted from aerobics and SKJ 2012 are believed to be good physical activity choices, especially for female adolescents to deal with anemia problems. The purpose of this study was to prove the implementation of reproductive health exercise on the hemoglobin levels of female adolescents. This study used 30 respondents as research subjects. The intervention group was given reproductive health exercises and Fe tablets for 4 weeks with a duration of 18 minutes 3 times a week. Blood collection are namely before after treatment and menstruation. The results of this study found an increase in hemoglobin levels. The average increase in hemoglobin level from $10.43 \mathrm{gr} / \mathrm{dL}$ to $13.98 \mathrm{gr} / \mathrm{dL}$ with an increase of $3.54 \mathrm{gr} / \mathrm{dL}$, by statistical test there was a significant difference in $p$-value $<0.05$. Meanwhile, the mean hemoglobin level of the intervention group with control was different with $p$-value $<0.05$. The conclusion of this study proves that the implementation of reproductive health exercise has an effect on the hemoglobin level of female adolescents.
\end{abstract}

Keywords: Gymnastics Reproductive health; hemoglobin; female adolescents.

\section{Introduction}

Adolescence is a period of rapid growth and development compared to childhood because of the transition from all forms of stages into adult life. WHO data (World Health Organization) shows there are around 350 million people or $23 \%$ of the population of Southeast Asia at that age in 2017 the population of adolescents (10-24) in Indonesia reaches $25.44 \%$ of the total population in Indonesia. Adolescence is characterized by patterns of identification of changes in growth, development, psychological risks of reproductive health and towards the process of sexual maturity [1-3].

Reproductive health is a comprehensive physical, psychological and social condition of individuals that is related to the process of reproduction, role, and scheme in all phases of life [4]. One of the changes in the reproductive system of female adolescents is menstruating. Menstruation is the decay of the inside of the uterine wall which has many blood vessels accompanied by eggs that are not fertilized by a sperm so that it moves the process of removing blood [5]

Physiologically, female adolescents experience menstruation and automatically bleeding every month. A lot of blood expenditure and long periods of menstruation will affect the condition of female adolescents. Research by Rupali et al said that menstrual patterns have a relationship with the incidence of anemia in Indian adolescents with $90.83 \%$ [6].

Female adolescents who experience menstrual bleeding every month and consuming foods containing iron substance cause the body to lack of iron substance reserves so that the hemoglobin level is low in the blood. Female adolescents with low hemoglobin levels are at risk of anemia [7]. Anemia is a condition of reduced blood hemoglobin level $<12 \mathrm{gr} / \mathrm{dL}$ in female adolescents [8] Other causes of female adolescents experience anemia, namely worm infections and low socio-economic conditions [9]

Globally, anemia problems in various developed and developing countries are easy to find. WHO data (World Health Organization) shows anemia patients in the world by $40 \%-88 \%$ occur in female adolescents [10] The prevalence of anemia in developed countries is $6 \%$ and developing countries $27 \%[2,9]$. According to WHO cases of more than $40 \%$ of events include anemia in the bad category in a country. There are 9 out of 10 people in developing countries having anemia [10]

According to WHO cases of more than $40 \%$ of events include anemia in the bad category in a country. There are 9 out of 10 people in developing countries having anemia [10]. Based on the Riskesdas data in 2013, there are up to $21.7 \%$ incidences of anemia in Indonesia. The proportion of anemia in Indonesia according to female sex characteristics is more dominant compared to men,

${ }^{*}$ Corresponding author: $\underline{\text { sarahfitria02@gmail.com }}$ 
presentation to women is $23.9 \%$ and man is $18.4 \%$ and based on the characteristics of the age group of 10-19year-old women who experience anemia as much as $49.1 \%$, age 5-14 years higher with anemia occurring $26.4 \%$, while age 15-21 years with the incidence of anemia $18.4 \%$ [11]. The results of the study on average at the age of 13 years old women first menstruated with the anemia prevalence of iron substance deficiency by $27.5 \%$ in Listiana's study [12]. The prevalence of anemia in Central Java is $57.1 \%$. Whereas the incidence of anemia in adolescents reaches $26 \%$ in Semarang [13].

The long-term impact on anemic female adolescents, if pregnant at the age of $>20$ years, the nutritional needs of the pregnancy will not be fulfilled optimally. Anemia can increase the number of complications, the risk of maternal death, fetal death, prematurity rates, and LBW (Low Birth Weight) [14].

Handling anemia problems start in adolescence because anemia is a crisis of women's health problems that has a long-term impact. According to the Indonesian Ministry of Health in 2017, the percentage of female adolescents who get $\mathrm{Fe}$ (iron) tablets in Indonesia is still very low at $13.8 \%$. The coverage of $\mathrm{Fe}$ (iron) tablets for female adolescents has not met the national target of $30 \%$. The aim of female adolescents given iron tablets is to reduce anemia [15]. The effectiveness of the consumption of $\mathrm{Fe}$ tablets results will be seen on day 5, where hemoglobin levels increase by $0.1 \mathrm{~g} / \mathrm{dl}$ in a day. Ery's study with $p$-value $<0.05$ said that hemoglobin levels were influenced by the behavior of taking iron tablets in female adolescents [16]

The strategy was given to overcome the problem of anemia as a complementary therapy for the administration of Fe tablets in the form of physical activity. Physical activity increases oxygen consumption because it is related to hemoglobin as a carrier protein that is in erythrocytes to reach the cell. Hemoglobin in the human body has an important function, namely the transport of oxygen from the respiratory organs (lungs) throughout the body. Physical activity is an activity carried out routinely, regularly and repeatedly to improve health status. Physical activity that is much in demand by the community, especially female adolescents is gymnastics $[17,18]$.

Gymnastics is a physical activity that can be done by everyone while adjusting the proportion of age [19]. Reproduction health gymnastics is a physical activity that requires adequate oxygen to obtain energy sources. Reproductive health exercise was adopted from aerobics and SKJ (Physical Fitness Exercise) in 2012 [20,21] Routinely doing reproductive health exercises will stretch the muscles that increase metabolic activity and facilitate blood circulation so that it activates the parasympathetic nerves which cause vasodilation of blood vessels that produce a large concentration of oxygen. With a large amount of oxygen in the body, there is a change in intramuscular osmotic pressure that pushes the vascular compartment into the interstitial space so that plasma volume decreases which causes reconstruction of red blood cells and iron transfer increases from the bone marrow to red blood cells resulting in increased hemoglobin production.[22-24]
Denis's research resulted in an increase in hemoglobin levels from $9.8 \mathrm{gr} / \mathrm{dL}$ to $13.7 \mathrm{gr} / \mathrm{dL}$ after being given aerobic exercise treatment. ${ }^{17}$ Provision of reproductive health exercises is expected to increase the hemoglobin level of female adolescents.

Provision of reproductive health exercises is given 3 times a week with a duration of 15-20 minutes for 4 weeks. In accordance with Asra's and Anam's research that gymnastics/exercise can increase hemoglobin levels, carried out 3 times a week and Purwanto's research said that the duration of physical activity of 15-30 minutes was considered sufficient if carried out continuously and preceded by heating and ended with cooling and Bruseghini's study said that by giving aerobic exercise for 4 weeks that of 40 subjects 37 of them had increased hemoglobin levels [25-28]

Based on the descriptions above, it is necessary to provide reproductive health exercise interventions for adolescents at school. Therefore, the researchers want to conduct a study entitled "Implementation of Reproductive Health Gymnastics on Female adolescents' Hemoglobin Levels."

\section{Research Method}

This is a quasi-experimental research with control group pre-test and post-test design. The population of this study was female adolescents aged 13-15 years in Junior High School 26 Semarang in 2019. The sample of this study were anemic female adolescents aged 13-15 years and fulfilling the inclusion criteria. The method of sampling in this study is nonprobability sampling with a purposive sampling technique, namely sampling with the determination of researchers based on inclusion criteria in the study. Inclusion criteria of this study: Female adolescents aged 13-15 years, girls with hemoglobin levels $8-<12 \mathrm{gr} / \mathrm{Dl}$, female adolescents willing to be respondents. Exclusion criteria for this study: Female adolescents with a history of disease: Thalassemia, hyperglycemia, leukemia, tuberculosis. To determine the difference in sample size, the average two groups:

$$
n 1=n 2=2\left[\begin{array}{c}
(Z \alpha+Z \beta) s \\
(x 1-x 2)
\end{array}\right]^{2}
$$

In which :

$\begin{array}{ll}\mathrm{Z} \alpha & : \text { Alpha standard deviate } \\ \mathrm{Z} \beta & \text { : Raw beta deviate } \\ \mathrm{S} & \text { : Combined standard deviate }\end{array}$

$\mathrm{X}_{1}-\mathrm{X}_{2}$ : the minimum difference in average is considered meaningful

Based on the calculation results, the sample size is at least 13 people fro each group. However, to avoid dropping out, it is estimated to be $10 \%$ in each group using the formula.

$$
\begin{aligned}
& \mathrm{n}^{\prime}=\frac{n}{(1-f)} \\
& \mathrm{n}^{\prime}=\frac{13}{(1-0,1)} \\
& \mathrm{n}^{\prime}=14.4
\end{aligned}
$$

Then each group has a sample of 15 people with a total sample of 30 people. 
Secondary data was obtained through a preliminary study in the health office regarding the highest prevalence of anemia among female adolescents in Junior High School 26 Semarang. Primary data was obtained directly by conducting research on research subjects. This study used anemic adolescent female subjects aged 13-15 years, researchers needed to seek approval as permission to conduct research to consider the ethical aspects of research. After reproductive health gymnastics products for female adolescents' gymnastics were validated by gymnastics experts and revised, a small group trial was conducted, this small group trial was conducted to determine the weaknesses and shortcomings and effectiveness of products after being used by female students. Data obtained in small scale trials would be used to revise the product before being used in the field trials. Inputs and suggestions on reproductive health gymnastic products are needed for product improvement. After the reproductive health gymnastics products were tested on a small scale and have been revised, the next step is to apply the product to research that has been validated by gymnastics experts.

Data collection in this study was collected by the researchers. Before conducting data collection on research respondents, researchers will conduct reproductive health exercise trials on the subject before being given intervention on the actual subject. Requesting a research permit through the Health Ministry's Health Applied Health Polytechnic Postgraduate Program addressed to the Public Health Office of Semarang and the Education Authorities and Junior High School which would be used as a trial for reproductive health gymnastics products.

Validation deals with the accuracy of the assessment tool for the concept being assessed so that it really assesses what should be assessed. Expert judgment is carried out to make improvements to the initial product design, namely reproductive health exercises, especially seen from the accuracy of the content, the form of the movement and to get the legitimacy from the parties concerned according to the scientific field. The expert validation in this research was validated by an expert of gymnastics at the Faculty of Sport Sciences, Semarang State University.

To help researchers in conducting this research, researchers chose to be assisted by enumerators who are gymnastics instructors/sports teachers.

After the reproductive health gymnastic SOP was arranged and has been consulted with experts in the gymnastics field, then the researchers would test the product, namely reproductive health exercises on the subject or respondent to be used as a trial. Product trials would be conducted in junior high school in Semarang. Product testing conducted in the field in junior high school aims to obtain product responses and revisions in the form of final products, namely reproductive health exercises.

After getting input from experts about products that have been tested in the field then the product will be revised according to suggestions or inputs to improve the product before the final product, namely reproductive health exercise, is used to the research respondents. After obtaining permission from the Principal to conduct research, researchers first recorded and recorded female students aged 13-15 years and filled out personal data. The researchers gave worm medicine to all anemic female adolescents aged 13-15 years, preparing research instruments and equipment.

If the participants agree to be sampled, it is necessary to fill out an informed consent sheet. In examining hemoglobin levels using the cyanmethemoglobin method by taking $10 \mathrm{ul}$ capillary blood to obtain anemic female adolescents who met pre-determined inclusion and exclusion criteria.

After getting anemia, the students who met the criteria to be sampled were the sample. Provide an explanation of the goals, benefits, risks and research procedures in advance to anemia female adolescents. Researchers provide counseling about anemia in female adolescents and alternative treatments by doing reproductive health exercises.

The researchers conducted a 3-minute bench test to assess the physical fitness of female adolescents before being given intervention.

Researchers and enumerators interviewed respondents about nutritional / food intake for the past 1 month with the SQ-FFQ observation sheet in the intervention and control groups. Interviews were conducted at the end of the study.

Examination of hemoglobin levels was carried out before the menstrual schedule and after menstruation by the cyanmethemoglobin method.

The intervention group was female adolescents who had anemia aged 13-15 years who received reproductive health exercises 3 times/week with a duration of 15-20 minutes for 4 weeks and Fe $60 \mathrm{mg}$ tablets as many as 30 tablets.

The control group was female adolescents who had anemia aged $13-15$ years who only got $\mathrm{Fe} 60 \mathrm{mg}$ tablets as many as 30 tablets for 4 weeks.

After being given intervention for 4 weeks, a reassessment of $10 \mathrm{ul}$ of blood for hemoglobin levels will be reassessed to be examined by the cyanmethemoglobin method using a photometer and a 3-minute bench test (YMCA) for adolescent physical fitness. Assessment of hemoglobin levels and physical fitness was carried out by the researchers themselves and assisted by 2 enumerators.

After each treatment had the final results of the measurement, the researchers made a comparison, namely which intervention group experienced changes in hemoglobin levels and adolescent female physical fitness.

The next step was data processing and analysis. Univariate analysis was used to determine all data distributions, where each variable examined in the study is processed in the form of a description.

Bivariate analysis was used to analyze the relationship between two variables, namely 1 independent variable and 1 dependent variable. In this study using the dependent and $t$ independent test with a parametric test.

The normality test was used for the distribution of the data being tested. The test used was the Shapiro-Wilk test because of the small sample size $(<50$ samples). If the significance value (Asym.sig) $>0.05$, the data is normal distribution. 
In conducting this research, researchers try to fulfill ethical considerations. There are principles of ethics, namely autonomy, benefit, respect for human dignity and justice. This research has fulfilled 4 principles and passed the health research ethics review of the Faculty of Dentistry, Sultan Agung Islamic University. with No. 037 / B.1-KEPK / SA-FKG / III / 2019 that have been registered [29]

\section{Results and Discussion}

\subsection{Product Description of Reproductive Health Gymnastics}

Based on suggestions and input from experts and teachers of education, such as the table above, the initial product is carried out repairs or revisions according to the suggestions and input. After the initial product was revised, the experts gave an assessment and it can be concluded that reproductive health gymnastics products for handling the problem of anemia in female adolescents are appropriate to be used in the field. The results of the final revision of reproductive health gymnastics products based on advice from gymnastics experts and teacher education are as follows: The calculation is clarified and repetition of movements adjusted to music.

The results of the revision of reproductive health gymnastics products as one of the innovations in handling anemia in female adolescents are carried out in several stages. Products that have been tested in SMP N 21 Semarang need to be revised to be good so that the acceptance of the product can be scientifically accountable. The final results of reproductive health gymnastics products based on advice from gymnastics experts and teacher education are as follows: Some movements are changed so that the movement is not difficult to memorize by the students and the video capture is more clarified.

Reproductive health exercises are well packaged, by showing the characteristics of female adolescents. Reproductive health exercises can be performed by allfemale adolescents. Reproductive health exercises can be used by teachers to apply sports learning in schools to improve female physical fitness, an increase in every educational goal that includes cognitive, affective and psychomotor.

Based on the research steps, the final product is in the form of reproductive health exercises that are suitable for the needs of female adolescents. The indicators of the success of this product are in the form of assessment sheets from gymnastics experts and health education teachers. The advantages of the products produced by reproductive health gymnastics can be used by sports teachers as an alternative to interdisciplinary learning in school subjects, reproductive health exercise is easy for female adolescents, reproductive health exercises can not only be carried out by anemia girls, but healthy female adolescents and dysmenorrhea doing these exercises, reproductive health exercises encourage the development of student movement skills, reproductive health exercises can improve cognitive, affective and psychomotor aspects of female students.

In Reproductive Health Gymnastics, researchers pay little attention to the proper stages of movement, because of the limitations of students in moving, due to lack of other physical activities besides sports in school, the count in music is absent, due to the limitations of researchers in finding sources that help in the process of making music and videos gymnastics.

\subsection{Univariate Analysis}

The description of respondents' characteristics in this study included a nutritional status and nutritional intake consisting of 15 treatment groups (giving reproductive health exercises and $\mathrm{Fe}$ tablets) and 15 control groups (giving Fe tablets only)

Table 1. Frequency Distribution of Respondents based on nutritional status and nutritional intake at the Intervention group and controls

\begin{tabular}{|c|c|c|c|c|c|}
\hline No. & Variable & $\mathbf{N}$ & $\begin{array}{l}\text { Intervention } \\
\text { group }\end{array}$ & $\begin{array}{l}\text { Control } \\
\text { Group }\end{array}$ & $P$ \\
\hline \multirow{3}{*}{1} & \multicolumn{5}{|c|}{ Nutritional Status } \\
\hline & Mean \pm SD & \multirow{2}{*}{15} & $\begin{array}{r}20,133 \pm \\
33,350\end{array}$ & $\begin{array}{l}20,487 \pm \\
3.5675\end{array}$ & \multirow{2}{*}{0,385} \\
\hline & Min-Max & & $14,9-26,2$ & $\begin{array}{l}15,9- \\
25,8\end{array}$ & \\
\hline \multirow{4}{*}{2} & \multicolumn{5}{|l|}{$\begin{array}{l}\text { Nutritional } \\
\text { Intake } \\
\text { (Energy) }\end{array}$} \\
\hline & & \multirow{3}{*}{15} & $2028,07 \pm$ & $1814,67 \pm$ & \multirow{3}{*}{0,198} \\
\hline & & & 505,253 & 393,739 & \\
\hline & Min-Max & & $1211-2717$ & $\begin{array}{l}1135- \\
2464\end{array}$ & \\
\hline \multirow{4}{*}{3} & \multicolumn{5}{|c|}{$\begin{array}{l}\text { Nutritional Intake } \\
\text { (Iron) }\end{array}$} \\
\hline & & \multirow{3}{*}{15} & $17,853 \pm$ & $14,120 \pm$ & \multirow{3}{*}{0,278} \\
\hline & & & 53,306 & 40,097 & \\
\hline & Min-Max & & $8,5-27,9$ & $5,6-18,4$ & \\
\hline \multirow{4}{*}{4} & \multicolumn{5}{|c|}{$\begin{array}{l}\text { Nutritional Intake } \\
\text { ( Vit C) }\end{array}$} \\
\hline & Mean \pm SD & \multirow{3}{*}{15} & $422,080 \pm$ & $69,667 \pm$ & \multirow{3}{*}{0,090} \\
\hline & & & 288,834 & 995,386 & \\
\hline & Min-Max & & $18,9-136,8$ & $\begin{array}{l}15,1- \\
415,6 \\
\end{array}$ & \\
\hline \multirow{4}{*}{5} & \multicolumn{5}{|c|}{$\begin{array}{l}\text { Nutritional Intake } \\
\text { (Protein) }\end{array}$} \\
\hline & Mean \pm SD & \multirow{3}{*}{15} & $60,850 \pm$ & $47,520 \pm$ & \multirow{3}{*}{0,064} \\
\hline & & & 198,621 & 159,615 & \\
\hline & Min-Max & & $36,3-91,1$ & $37-100,5$ & \\
\hline
\end{tabular}


Based on Table 1, this shows the nutritional status of the Intervention group ranged from 14.9 to 26.2 with an average of 11.3 , while the control group ranged from 15.9-25.8 with a mean of 20.49. Nutritional status based on BMI (Body Mass Index) has a $p$ value $>0.05$, meaning that there is no significant difference between the nutritional status of female adolescents in the intervention group and controls.

On the results of nutritional intake (energy) in the intervention, group ranged from 1211-2717 with an average of 1506, while in the control group ranged from 1135-2464 with an average of 1329. Respondents' nutritional intake (energy) had a $\mathrm{p}$ value $>0.05$, meaning that there is no significant difference between the nutrition (energy) of the female adolescent in the intervention group and controls.

On the results of nutritional intake (iron tablets) in the Intervention group ranged from 8.5 to 27.9 with an average of 19.4, while in the control group ranged from 5.6-18.4 with an average of 12.8. Nutritional intake (iron tablets) of respondents have a p-value of $>0.05$ meaning that there is no significant difference between the nutritional intake (iron tablets) of female adolescents in the intervention group and controls.

On the results of nutritional intake (Vit C) in the Intervention group and controls ranged from 18.9 to 136.8 with an average of 117.9, while the control group ranged from 15.1-415.6 with an average of 400.5 Nutritional intake (Vit $\mathrm{C}$ ) respondents have a $\mathrm{p}$ value $>0.05$, meaning that there is no significant difference between the nutritional intake (Vit C) of female adolescents in the intervention group and controls.

The results of nutrition (protein) intake in the intervention group ranged from 36.3 to 91.1 with an average of 54.8, while the control group ranged from 37 100.5 with an average of 63.5 . The nutritional intake (protein) of the respondents have a $\mathrm{p}$ value $>0.05$, meaning that there is no significant difference between the nutritional intake (protein) of female adolescents at the intervention group and controls.

\subsubsection{Respondents' Characteristics}

Based on the results of the analysis of the characteristics of respondents with statistical tests obtained by the characteristics of respondents, namely nutritional status and nutritional intake (energy, protein, iron and Vit C) at the intervention group and controls do not significantly related to hemoglobin levels and physical fitness after giving reproductive health exercises with administration Fe tablets for 4 weeks.

\subsubsection{Nutritional Status}

Characteristics of respondents based on BMI (Body Mass Index) in this study affect the incidence of anemia in female adolescents. The average nutritional status of female adolescents is 26.2 and a minimum of 14.9. The WHO BMI assessment category is normal, which is 18.5 $-<25.0$ [30].

\subsubsection{Nutritional Intake (Energy, iron, protein and Vit C)}

Female adolescents need to consume a variety of foods to meet the needs of energy, protein, and micronutrients that function to increase blood volume and hemoglobin [31, 32].

The results showed that the average energy intake of female adolescents in the Intervention group met the RDA and the control group was still below the RDA of 2125 $\mathrm{kcal} /$ day. While the nutritional intake (iron, protein, Vit C) at both the intervention group and controls was still below the AKG, the energy of girls aged $13-15$ years is 69 $\mathrm{mg}$ protein, $65 \mathrm{mg}$ vitamin $\mathrm{C}$, and $22 \mathrm{mg}$ iron [33]

YouFemale adolescents really need protein nutrition in their bodies, because protein is a nutrient that serves to maintain cells or tissues that are formed. Almost all systems of human organs are dominated by protein, both hormones, blood nutrients and components of the skin layer [31-34]

One of the causes of iron deficiency anemia, namely inadequate nutrient intake and inadequate absorption and an increase in the need for iron for the formation of red blood cells that commonly occurs during infancy, puberty (adolescence), pregnancy and lactation. 35 Iron needs for female adolescents are needed to form hemoglobin which increases and prevents anemia because of iron loss during menstruation [31]

Vitamin $\mathrm{C}$ intake in the body is needed by female adolescents because vitamin $\mathrm{C}$ functions to accelerate absorption in the process of hemoglobin formation. Other substances as inhibitors of iron absorption in the formation of hemoglobin such as consuming tea, coffee, and milk should be avoided. Iron absorptive inhibitors are derived in part from plants. The most powerful inhibitors are polyphenol compounds such as peasants in tea. Tea can reduce absorption up to $80 \%$ as a result of the formation of an iron complex [35,36]

\subsubsection{Frequency Distribution of Hemoglobin Levels}

The results of statistical tests of hemoglobin levels before and after treatment were given to the intervention group (giving reproductive health exercises and Fe tablets) and control groups (giving Fe tablets). This shows that the mean and standard deviation of hemoglobin levels after being given treatment at the Intervention group is higher than the control group which is $103.980 \pm 2.0760 \mathrm{gr} / \mathrm{dL}$ and $12.269 \pm 1.7778 \mathrm{gr} / \mathrm{dL}$. The results can be obtained in Table 2. 
Table 2. Analysis of Hemoglobin Levels

\begin{tabular}{|c|c|c|c|c|c|}
\hline \multirow[b]{2}{*}{$\begin{array}{c}\text { Varia } \\
\text { ble }\end{array}$} & \multirow[b]{2}{*}{$\mathbf{N}$} & \multicolumn{2}{|c|}{$\begin{array}{c}\text { Intervention } \\
\text { group }\end{array}$} & \multicolumn{2}{|c|}{ Control group } \\
\hline & & $\begin{array}{l}\text { Mean } \pm \\
\text { SD }\end{array}$ & $\begin{array}{l}\text { Min- } \\
\text { Max }\end{array}$ & $\begin{array}{l}\text { Mean } \pm \\
\text { SD }\end{array}$ & $\begin{array}{l}\text { Min } \\
- \\
\text { Max }\end{array}$ \\
\hline $\begin{array}{l}\text { Hemog } \\
\text { lobin }\end{array}$ & & & & & \\
\hline Pre & 15 & $\begin{array}{l}10,433 \pm \\
0,9424 \\
\end{array}$ & $\begin{array}{l}8,8- \\
11,9 \\
\end{array}$ & $\begin{array}{l}10,367 \pm \\
1,1255 \\
\end{array}$ & $\begin{array}{l}8,2- \\
11,9 \\
\end{array}$ \\
\hline Post & 15 & $\begin{array}{l}13,980 \pm \\
2,0706\end{array}$ & $\begin{array}{l}9,3- \\
16,3\end{array}$ & $\begin{array}{l}12,269 \pm \\
1,7778\end{array}$ & $\begin{array}{l}8,7- \\
14,8\end{array}$ \\
\hline
\end{tabular}

\subsection{Dependent T Test}

Hemoglobin levels and physical fitness were measured before and after treatment for 4 weeks. Distribution of hemoglobin level and physical fitness data at the Intervention group and controls were normally distributed so that they used paired t-test.

Differences in hemoglobin levels before and after menstruation at the intervention group (reproduction of reproductive health exercises and Fe tablets) and control groups (Fe tablet removal) can be seen in Table 3 with results that at the Intervention group hemoglobin levels before menstruation 10,967 $\mathrm{gr} / \mathrm{dL}$ and after menstruation $8,813 \mathrm{gr} / \mathrm{dL}$ decreased by $2.154 \mathrm{gr} / \mathrm{dL}$, while the control group averaged $10.340 \mathrm{gr} / \mathrm{dL}$ and after treatment 8.947 gr /dL and decreased 1,393 gr / dL with a p-value $<0.05$, which means that there are differences in hemoglobin levels in the intervention group and controls before and after menstruation.

Table 3. Analysis of Hemoglobin Levels Before and After Menstruation

\begin{tabular}{|c|c|c|c|c|c|c|}
\hline \multirow[t]{2}{*}{$\begin{array}{c}\text { Variab } \\
\text { le }\end{array}$} & \multirow[t]{2}{*}{$\mathbf{N}$} & \multicolumn{2}{|c|}{$\begin{array}{l}\text { Intervention } \\
\text { group }\end{array}$} & \multicolumn{2}{|c|}{ Control group } & \multirow[t]{2}{*}{$\mathbf{P}$} \\
\hline & & $\begin{array}{l}\text { Mean } \\
\pm \text { SD }\end{array}$ & $\begin{array}{l}\text { Min- } \\
\text { Max }\end{array}$ & $\begin{array}{l}\text { Mean } \pm \\
\text { SD }\end{array}$ & $\begin{array}{l}\text { Min- } \\
\text { Max }\end{array}$ & \\
\hline $\begin{array}{c}\text { Hemog } \\
\text { lobin }\end{array}$ & & & & & & \\
\hline $\begin{array}{c}\text { Pre } \\
\text { Menstr } \\
\text { uation }\end{array}$ & 15 & $\begin{array}{c}10,96 \\
7 \pm \\
0,747 \\
1\end{array}$ & $\begin{array}{c}9- \\
11,9\end{array}$ & $\begin{array}{c}10,340 \\
\pm \\
1,0218\end{array}$ & $\begin{array}{l}8,5- \\
11,8\end{array}$ & $\begin{array}{c}0,00 \\
0\end{array}$ \\
\hline $\begin{array}{c}\text { Post } \\
\text { Menstr } \\
\text { uation }\end{array}$ & 15 & $\begin{array}{c}8,813 \\
\pm 0,52 \\
76 \\
\end{array}$ & $\begin{array}{c}8- \\
10,8\end{array}$ & $\begin{array}{l}8,947 \pm \\
0,7530\end{array}$ & $\begin{array}{l}8,0- \\
10,9\end{array}$ & $\begin{array}{c}0,00 \\
0\end{array}$ \\
\hline
\end{tabular}

Differences in hemoglobin levels before and after treatment at the intervention group (reproduction of reproductive health exercises and Fe tablets) and control groups (Fe tablet drilling) can be seen in Table 4 with the results that at the intervention group hemoglobin levels before treatment 10,433 gr / $\mathrm{dL}$ and after treatment 13,980 gr / dL there was an increase of $3.547 \mathrm{gr} / \mathrm{dL}$, while the control group had an average before treatment $10.367 \mathrm{gr} /$ $\mathrm{dL}$ and after treatment $12.269 \mathrm{gr} / \mathrm{dL}$ and had an increase of $1.902 \mathrm{gr} / \mathrm{dL}$ with a $\mathrm{p}$-value $<0.05$ which means that there are differences in hemoglobin levels in the
Intervention group and controls before and after treatment.

Table 4. Analysis of Differences in Hemoglobin Levels Before and After Intervention in the treatment and control groups

\begin{tabular}{|c|c|c|c|c|c|}
\hline Variable & $\mathbf{N}$ & Mean & SD & $\begin{array}{c}\text { Averag } \\
\text { e } \\
\text { Differe } \\
\text { nce }\end{array}$ & $P$ \\
\hline \multicolumn{6}{|c|}{ Hemoglobin Levels } \\
\hline $\begin{array}{c}\text { Pre- } \\
\text { intervention }\end{array}$ & \multirow[t]{2}{*}{15} & 10,433 & 0,9424 & \multirow{2}{*}{3,547} & \multirow{2}{*}{0,000} \\
\hline $\begin{array}{c}\text { Post- } \\
\text { intervention }\end{array}$ & & 13,980 & 2,0760 & & \\
\hline Pre control & \multirow{2}{*}{15} & 10,367 & 1,1255 & \multirow{2}{*}{1,902} & \multirow{2}{*}{0,001} \\
\hline Post control & & 12,269 & 1,7778 & & \\
\hline
\end{tabular}

\subsection{Independent t-test}

The following are the results of the independent t-test for hemoglobin levels and physical fitness at the Intervention group and controls.

Differences in hemoglobin levels before and after treatment at the Intervention group (reproduction of reproductive health exercises and Fe tablets) and control groups (Fe tablet firing) can be seen in Table 5, showing the results that the average hemoglobin level after being treated at Intervention group $13.980 \mathrm{gr} / \mathrm{dL}$ and control group averaged $12.269 \mathrm{gr} / \mathrm{dL}$ with differences in mean of $1.7107 \mathrm{gr} / \mathrm{dL}$ and $\mathrm{p}$-value $=0.022$ which means that there are differences in hemoglobin levels in the Intervention group and controls after being given treatment.

Table 5. Hemoglobin level differences between treatment and control groups

\begin{tabular}{|c|c|c|c|c|}
\hline Variable & Mean & SD & $\begin{array}{c}\text { Mean } \\
\text { Difference }\end{array}$ & p-value \\
\hline \multicolumn{5}{|c|}{ Hemoglobin (Post) } \\
\hline $\begin{array}{l}\text { Interventi } \\
\text { on }\end{array}$ & 13,980 & 2,0706 & 1,7107 & \multirow[t]{2}{*}{0,022} \\
\hline Control & 12,269 & 1,7778 & & \\
\hline
\end{tabular}

Seeing the difference in hemoglobin levels between the Intervention group given reproductive health exercises with Fe tablets and control groups given Fe tablets alone, the independent t-test statistical tests were carried out. Based on the results of the independent t-test obtained p-value $0.022<0.05$, it can be concluded that the provision of reproductive health exercises together with Fe tablets for 4 weeks on a regular basis significantly influences the changes in hemoglobin levels of 13.980 higher than the control the group is 12,269.

The results above can be explained that giving reproductive health exercises to anemic female adolescents can increase hemoglobin levels. Gymnastics is a physical activity that is often associated with female adolescents. Physical activity exercised routinely would have a good impact on the system and female body organs [37]. One innovation to deal with the problem of anemia 
is the provision of reproductive health exercises. Gymnastics movement trains female adolescents to regulate their breath so that oxygen consumption in the body is maximal and affects the work system of the organs, namely the volume of blood and blood cells $[31,38]$

Reproductive health exercises carried out routinely by female adolescents 3 times a week in 4 weeks with a duration of 15-20 minutes consisting of heating, core and cooling movements will stretch the muscles which increase metabolic activity and facilitate blood circulation thereby activating the parasympathetic nerves that cause vasodilation blood vessels that produce a lot of oxygen concentration. With a large amount of oxygen in the body, there will be a change in intramuscular osmotic pressure that pushes the vascular compartment into the interstitial space so that plasma volume decreases which causes the reconstruction of red blood cells and iron transfer increases from the bone marrow to red blood cells resulting in increased hemoglobin production [23-25]

Physical activity carried out with a frequency of 3 times a week according to Asra Askari et al was effective in increasing hemoglobin levels [25]. By routinely carrying out reproductive health exercises coupled with the consumption of $\mathrm{Fe}$ tablets will accelerate the absorption of iron in the body. Iron absorption is by reducing ferric iron $\left(\mathrm{Fe}^{3+}\right)$ to Ferro $\left(\mathrm{Fe}^{2+}\right)$ in the intestine so that it is easily absorbed, the reduction process will become even greater if the $\mathrm{pH}$ in the stomach becomes more acidic [39]

The study by Denis stated that there was an increase in the average hemoglobin level from $9.8 \mathrm{gr} / \mathrm{dL}$ to 13.7 $\mathrm{gr} / \mathrm{dl}$. After being given treatment, it means that there is an increase of $3.9 \mathrm{gr} / \mathrm{dL}$ after being given aerobic exercise treatment. This study proves that giving aerobic exercise 5 times/week for 3 weeks can increase hemoglobin levels in female adolescents [17]

\subsection{Research Limitations}

There is no calculation in music, because of the limitations of researchers in finding sources that help in the process of making gymnastic music and videos. This study only did SQ-FFQ sheets without controlling the respondent's nutritional intake.

\section{Conclusion}

On the results of the research conducted on 30 respondents with the provision of reproductive health exercises 3 times a week with a duration of 15-20 minutes for 4 weeks found an effective increase: Hemoglobin level 3,547 gr /dL, Physical fitness $23 \mathrm{x} /$ minute, There were differences in hemoglobin levels in Intervention group and control after being given treatment with a p-value of 0.022 , Expected to routinely carry out physical activities of reproductive health exercises 3 times a week accompanied by consumption of $\mathrm{Fe}$ tablets as an alternative prevention of anemia in female adolescents.
Thank you to all parties who have helped the researcher to conduct this study. To Mrs. Dra. Anny Winarsih, M.Pd that has given permission to the researchers to conduct research in SMP N 26 Semarang. To Ms. Tika as a sports teacher who accompanied the researcher while researching. to Dr. Rr Sri Endang Pujiastuti, SKM, MNS as the 1st supervisor and Mr. Dr. Donny K. Mulyantoro, M.Kes as the 2nd supervisor who has guided and provided suggestion and advises to the researcher to complete this final project.

\section{References}

1. Z. Lassi, K. Wazny, R.A. Salam, J.K. Das, Z.A. Bhutta, An Unfinished Agenda on Adolescent Health: Opportunities for Interventions, Seminar in Perinatology (2015)

2. M.J. Hindin, C.S. Christiansen, J. Ferguson, Setting Research Priorities for Adolescent Sexual and Reproductive Health in Low- and Middle-Income Countries, Bull World Health Organization (WHO) 91, 10-18 (2013)

3. SDKI, Indonesian Demographic and Health Survey 2017: Adolescent Reproductive Health, BKKBN (2017)

4. E. Purwoastuti, E. Walyani, Guide to Reproductive and Family Planning Health Material, Yogyakarta: Pustaka Baru Press (2015)

5. S.P. Shah, R. Nair, P.P. Shah, D.K. Modi, S.A. Desai, L. Desai, Improving Quality of Life with New Menstrual Hygiene Practices among Adolescent Tribal Girls in Rural Gujarat, India, Reproductive Health Matters 21, 41 (2013)

6. P. A. Rupali, K. S. Sanjay, R.A. Patle, Anemia: Does it Have Effect on Menstruation?, Scholars Journal of Applied Medical SciencesOnline Sch. J. App. Med. Sci 3(1G), 514-517 (2015)

7. H.V. Meulen, M. Sholzberg, Iron Deficiency and Anemia in Patients with Inherited Bleeding Disorders, Tranfusion and Aphresis Science (2018)

8. T.S. Alaqzam, A.C. Stanley, P.M. Simpson, V. Flood, S. Menon, Treatment Modalities in Adolescents WHO present With Heavy Menstrual Bleeding, Journal of Pediatric and Adolescent Gynecology (2018)

9. A. Fajrin, Socio-Economic Risk Factors, Protein Intake, Iron Substance to Anemia in School Children, Jurnal Gizi Indonesia 35(1), 22-29 (2012)

10. Organization, World Health (WHO), The Global Prevalence of Anemia in 2011, WHO (2011)

11. RISKESDAS, Indonesian Basic Health Research, Kementrian Kesehatan RI (2013)

12. A. Listiana, Analysis of Factors Associated with the Occurrence of Iron Nutrition Anemia in Young Women in Terbanggi Besar 1 Vocational School in Central Lampung, Jurnal Kesehatan 7(3), 455-469 (2016)

13. Dinas Kesehatan, Health Profile in Central Java, DINKES JATENG (2018)

14. M.T.Goswami, G. Pranab, M.B. Narayan, D. Puspendra, J. Vandana, G. Sandip, Prevalence and Determinants of Anaemia and Effect of Different Interventions Amongst Tea Tribe Female 
adolescents Living in Dibrugarh District of Assa, Clinical Epidemiology and Global Health (2015)

15. KEMENKES, Indonesia's Health Profile in 2017 , KEMENKES RI (2017)

16. E. Susanti, M. Ulfa, Relationship between Drinking Behavior of Iron Tablets in Young Women and Hemoglobin Levels. Journal of Nurses and Midwifery, 1(1) (2014)

17. R. Denis, J. Conway, Iron Deficiency and Aerobic Endurance Performance in a Female Club Runner/ Journal of Science and Sport (2018)

18. G.B. Ibanez, Z. Sanche, Penafiel, Iron Deficiency Anemia, Rewista Medica del Hospital General Mexico (2015)

19. Barker, et al, Physical Activity, Sedentary Time, TV Viewing, Physical fitness and Cardiovascular Disease Risk In Adolescents: The HELENA Study, International Journal of Cardiology (2017)

20. A. Pomatahu, Aerobics for Lung Health, Gorontalo: Ideas Publishing (2016)

21. Kementrian Pemuda dan Olahraga, SKJ (Physical Fitness Gymnastics) 2012, Jakarta Pusat (2012)

22. L. Sherwood, Human Physiologi: from Cell to System (6 Ed), Brahm U. Pendit Jakarta: EGC (2011)

23. J. Gilrichrist, E. Andree, C. Sabiston, D. Mack, Body Pride and Physical Activity: Differential Fitness-Associations between and Apprearance Related Pride in Young Adult Canadian, Journal Medicine (2018)

24. Benham, et all, Significant Dose-Response Relationship between Exercise Adherence and Hemoglobin A1C Change for Aerobic Training but Not Resistance or Combined Training, Canadians Journal of Diabetes (2018)

25. A. Askari, B. Askari, A. Mahdivand, M.A.S. Sharif, The Effect of Eight Weeks of Aerobic Training on Vo2max and Indices in 30-45 Years Old NonAthlete Women, Iranian Journal of Health and Physical Activity 4(1), 29-36 (2013)

26. M.S. Anam, The Effects of Diet and Exercise on Body Mass Index, Physical Fitness, Hscrp and Lipid Profile in Obese Children, Masters thesis Diponegoro University (2010)

27. Purwanto, The Impact of Aerobic Gymnastics on Body Endurance and Disease, Jurnal Media Ilmu Keolahragaan Indonesia 1 (2011)

28. Bruseghini, et all, Effect of Eight Weeks of Aerobic Interval Training and if Isoinertial Resistance Training on Risk Factors of Cardiometabolic Disesases and Exercices Capacity Inhealthy Elderly Subject, Impact Journal 6, 19 (2015)

29. M.R. Ulum, Y.W. Heri, The Journal of Educational Development, J. Educ. Dev.6(JED), 106-113 (2017)

30. KEMENKES RI, Technical Guidelines for Monitoring Nutritional Status of Adults with Body Mass Index (BMI), Jakarta: KEMENKES RI

31. KEMENKES RI, Balanced Nutrition Guidelines, Jakarta: KEMENKES RI (2014)

32. D. Sekhar, L. Kolb, E. Schaefer, L. Paul, Risk Based Questinnaires Fail to Detect Adolescent Iron Deficiency and Anemia, The Journal OF Pediatric
(2017)

33. KEMENKES, No. HK/03.03/V/0595/2016/Tentang Pemberian TTD pada Remaja Putri Dan WUS, Direktorat Jenderal Kesehatan Masyarakat. KEMENKES RI (2016)

34. N. Vijayakumar, Z.O. Macks, E.A. Shirtcliff, J. Pferfer, Puberty and the Human Brains: Insight into Adoloescent Development, Neuro Science and Behavioral Reviews 92, 417-436 (2018)

35. M.B. Arisman, Nutrition in the Life Cycle: Nutrition Science Textbook Edition 2, Jakarta: EGC (2010)

36. Varney et al, Midqife Pocket Book Edition 2, Jakarta: EGC (2010)

37. A. Setyowati, S. Suhartono, N. Ngadiyono, P.R.S. Endang, D. Dyah, Effect of Yoga on Duration of the Second Stage of Labor and Perineal Rupture in Primigravida Mothers, Belitung Nurs J 3(6), 702706 (2017)

38. D. Rattehalili. L. Pickard, C. Tselepis, N. Sharma, T. Iqbal, Iron Deficiency without Anemia: Do not wait for the Haemoglobin To drop?, Health Policy and Technology 2 (2013)

39. J. Widya, Relationship between the Causal Factors and the Incidence of Anemia in Melur Health Center, J. Kebidanan 8, 25-28 (2017) 